\title{
Determinants of Micro-Insurance Demand in Jimma Zone
}

\author{
Aregu Asmare*, Abel Worku** \\ * Department of Management, College of Business and Economics, P. O. Box: 387 Jimma University, Ethiopia \\ ** Department of Accounting and Finance, College of Business and Economics, P. O. Box: 387 Jimma University, Ethiopia
}

\begin{tabular}{|c|c|}
\hline ARTICLE INFO & A B S T RACT \\
\hline $\begin{array}{l}\text { Keywords: } \\
\text { Demand, } \\
\text { Microinsurance, } \\
\text { Poverty, } \\
\text { Risk, } \\
\text { Vulnerability } \\
\\
\text { Kata Kunci: } \\
\text { Kebutuhan, } \\
\text { asuransi mikro, } \\
\text { kemiskinan, } \\
\text { risiko, } \\
\text { kerentanan }\end{array}$ & $\begin{array}{l}\text { Vulnerability to risk is a constant factor in the lives of the poor and } \\
\text { a cause of persistent poverty. Microinsurance offers one approach } \\
\text { to mitigate the risk, yet demand is relatively low in developing } \\
\text { countries. Thus, the aim of this study was investigating determinants } \\
\text { of microinsurance demand in Jimma Zone. The data used in this } \\
\text { study was cross sectional which collected from households using } \\
\text { structured questioner and in-depth interview with officials of insurance } \\
\text { companies and microfinance institutions that provides microinsurance } \\
\text { product. The collected data was analyzed using multinomial logistic } \\
\text { regression model. The findings of the study show that household size, } \\
\text { employment status, level of education, adequacy of micro-insurance } \\
\text { supply, delivery channel, premium, monthly income, insurable asset, } \\
\text { financial literacy, trust, and risk aversion has significant impact on the } \\
\text { demand for microinsurance products, whereas age, gender, adverse } \\
\text { selection and moral hazard, religion and peer influence has insignificant } \\
\text { impact on household's demand for microinsurance products. }\end{array}$ \\
\hline
\end{tabular}

SARI PATI

Kerentanan pada risiko adalah faktor konstan dalam kehidupan orang miskin dan penyebab kemiskinan menjadi persisten. Asuransi mikro menawarkan satu pendekatan untuk memitigasi risiko, namun permintaan akan ini relatif rendah di negara-negara berkembang. Tujuan penelitian ini adalah mengkaji faktor yang menentukan dari permintaan asuransi mikro di zona Jimma. Data yang digunakan dalam penelitian adalah lintas bagian, yang dikumpulkan dari penghuni-penghuni rumah tangga menggunakan kuesioner terstruktur dan wawancara mendalam dengan pejabat perusahaan asuransi serta lembaga keuangan mikro yang menyediakan produk asuransi ini. Data yang terkumpul dianalisis menggunakan model regresi logistik multinomial. Temuan penelitian menunjukkan bahwa ukuran rumah tangga, status pekerjaan, tingkat pendidikan, kecukupan pasokan asuransi mikro, saluran pengiriman, premi, pendapatan bulanan, aset yang dapat diasuransikan, literasi keuangan, kepercayaan dan penghindaran risiko, memiliki dampak
Corresponding author: areguasmare2@gmail.com 
signifikan terhadap permintaan produk asuransi mikro, sedangkan usia, jenis kelamin, seleksi yang merugikan dan bahaya moral, agama, dan pengaruh teman sebaya, memiliki dampak yang tidak signifikan pada permintaan rumah tangga untuk produk asuransi mikro.

(C) 2018 IRJBS, All rights reserved.

\section{INTRODUCTION}

Micro-insurance or the insurance for the poor has been considered as «the next revolution» in addressing risks and vulnerability in low-income countries (Morduch, 2006). Life is risky for the poor in developing countries. Illnesses, natural disasters, unemployment, and accidents affect this segment of the population more severely than others due to their lack of formal insurance and their limited social safety nets. Many rely on informal transfers from friends, families, and relatives; however, such transfers often are deficient compared to what is needed. Microinsurance has come to be seen as an important means of managing risk for the poor, yet demand is relatively low in developing countries (Cole et al. 2013; Giné et al. ,2008; Jowett ,2003; \&Thornton et al. ,2010).

Even though micro-insurance is supplied, the demand for micro-insurance in developing countries is low in comparison to expected demand based on expected utility theory. Furthermore, an increasing number of empirical studies investigating micro-insurance demand in developing countries find that risk aversion leads to less, instead of more, take up of micro-insurance (Giné et al., 2008; Ito and Kono, 2010; Clarke and Kalani, 2011; Dercon et.al, 2011). This assumption contradicts with the underlying expected utility theory namely demand for insurance is higher for risk averse individuals who use insurance to avoid the risk of loss (Pratt, 1964; Mossin, 1968; Feldstein, 1973; Schlesinger and Doherty, 1985) the same is true for Ethiopia, vulnerability to risk, a constant factor in the lives of the poor, microinsurance offers one approach to mitigating risk, yet demand is disappointingly low majority of poor peoples have managed with their own means, very few have access to formal insurance and depend on informal mechanisms to cope with shocks (Shifa, 2012). Micro-insurance is at infant stage in Ethiopia according to recent estimates, out of the total potential market only 1.9 percent is reached by the existing micro-insurance schemes (Micro-insurance Network,2016).

Regarding research studies that have been conducted on micro-insurance demand different researchers examined the issue (Huber, 2012; Saqware ,2012; Eling et.al ,2013; Christiana ,2016; and Ndurukia et.al ,2017) conducted their studies on determinants of micro-insurance demand in developed, emerging and developing countries focusing on different sets of factors demographic, economic, institutional and personal related factors which influence micro-insurance demand. However, the finding is not consistent due to difference in economic, social cultural, financial, regulatory and operating environments. Therefore, it needs further investigation in socio economic and cultural context of Ethiopia particularly in Jimma zone. 
Furthermore, the literature revealed that prior researchers adopt a quantitative research approach only without considering its limitation and most of the studies focused on specific microinsurance product so the researchers fill these gap by adopting mixed research approach which provides a better understanding about research problems than either approach alone and brings robustness to the research findings and by including all micro-insurance products. At last, while we see in Ethiopia, determinants of micro-insurance demand is untouched issue only one study conducted by Tadesse and Brans (2012) which the variables are not tested statistically. Other studies focused on landscape of micro-insurance by Shifa, (2012) and prospects and challenges of microinsurance by Smith and Chamberlain (2010). Hence, based on the aforementioned justification this study designed to investigate determinants of micro-insurance demand in Jimma zone.

\section{LITERATURE REVIEW}

\section{Empirical studies determinants of micro-insurance demand}

Under this section previous studies conducted on micro-insurance demand in different level of economies were reviewed as follows.

Huber (2012) in his study of the determinants of Micro Life Scheme demand in Indonesia collated data on 208 microfinance customers through personally-administered questionnaires in the urban and semi-urban area of Jakarta. The study employed both descriptive tools and the Binary Probit Model. The result based on marginal effects probit regression analysis, support earlier findings regarding the positive influence of education and household wealth on life insurance uptake. In addition, economic capacity measurements deemed more appropriate for low-income households are introduced and corroborate an unambiguous strong positive influence of households relative economic capacity. Further, positive influence is found for respondents financial literacy and product understanding as well as client trust attitude and brand recognition. A strong negative life-cycle effect is revealed when taking into account economic self-sufficiency of dependents.

Saqware (2012) conducted a study in Tanzania on micro-insurance demand by using primary data. The investigation includes three stages; to begin with, family's significant risk exposures were examined, also hazard adapting methods which were set up were analyzed and thirdly, a probit regression examination was ran to build up the relationship between families' characteristics and the demand for informal micro-insurance product. The result of regression analysis reveals that employment, marital status, utilization of the services of MFIs, education, exposure to risk and knowledge about micro-insurance are critical determinants of micro-insurance products. Knowledge about micro-insurance and trust of providers of micro-insurance products were found to have a positive and insignificant effect on the demand for micro-insurance products. As opposed to expectations, the empirical investigation demonstrates that income is a noteworthy determinant with a negative effect on the demand for micro-insurance scheme.

Eling et.al (2013) that reviewed studies on the factors affecting the demand for micro-insurance picked out twelve critical elements influencing micro-insurance purchase including gender, age, risk exposure, quality of service, informal risk sharing, financial literacy, religion, trust and peer effects, non-performance risk, risk aversion, wealth and price.

Christiana (2016) investigated the determinants of micro-insurance in Ghana by employing cross sectional survey and multistage sampling procedure were used to collect data from 400 households in the Kumasi metropolis. The author used both descriptive and inferential analytical methods. Both the binary and multinomial logistic models were employed to determine the factors 
influencing households demand for microinsurance schemes. The result reveals that level of education; price, risk aversion, financial literacy, peer influence and quality of service are the main factors that influence the demand of microinsurance.

Ndurukia et.al (2017) examined the determinants of demand for micro-insurance services in Kenya. The study adopted cross sectional survey design. The target population was insurance service providers in Kenya licensed by the Insurance Regulatory Authority (IRA). Sampling technique was stratified random sampling. A questionnaire was used in the collection of primary data which was analyzed using Statistical Package of Social Sciences (SPSS). Analysis of data was done using descriptive and inferential statistics. Regression and correlation analysis was done to test the relationship between the study variable. The study findings indicated that risk exposure, price, and access to credit and income level are positive and significant determinants of micro-insurance demand. While price of insurance has a negative and significant impact on micro-insurance demand.

\section{Determinants of micro-insurance demand in Ethiopia}

Tadesse and Brance (2012) examined the risk, coping mechanisms, and factors in the demand for micro-insurance in Ethiopia. The author classifies target populations in to four socioeconomic systems of Ethiopia: low-income urban workers in Addis Ababa; agro-pastoralists in Hagere Mariam, Oromia; pastoralists in Yabello, Oromia; and coffee farmers in the Southern Nations, Nationalities and People's Region (SNNPR). The result of the study confirms that accessibility of insurance products, trust in specific insurance products, and perception of insurance's value affects the demand for microinsurance in Ethiopia.

Smith and Chamberlain, (2010) analyzed the major challenges of micro-insurance investment in Ethiopia. The result indicated that lack of infrastructure (limited health service), market barriers (limited experience to date with retail and life investment) and lack of delivery channel (unsupportive environment of intermediaries) are major challenges of micro-insurance investment in Ethiopia. Although, study pointed out major prospects and challenges from the supply, demand and regulatory frame work perspective, but those prospects and challenges' significance level are not tested. In addition, the study used only qualitative study that can't enables us to make an inference to the total population.

Shifa, (2012) investigated the landscape of microinsurance by exploring opportunities and challenge. Similar to Smith and Chamberlain, he stated that lack of infrastructure (on whether data) and lack of delivery channel are main challenges of microinsurance practice. Notwithstanding he stated several factors, the same to the aforementioned studies in Ethiopia he didn't tested the significance of those factors and used only qualitative study to investigate the issue. Hence, this can't enable us to make generalization to the population.

\section{METHODS}

The data used in this study was cross sectional and collected from households in Jimma zone using structured questioner and the data is collected in February 02-26, 2018. A total of 400 questionnaires were distributed for respondents and 389 questionnaires were returned and used for analysis purpose. In addition, in-depth interview was conducted with 12 top officials of insurance companies and microfinance institutions that provides micro-insurance product. The collected data was analyzed using multinomial logistic regression model and the researchers tested the variables in the study as major determinants of micro-insurance demand in Jimma Zone.

The following empirical model was used in estimating the parameters for the variables in this study: 
$\mathrm{Yi}=\beta 0+\beta 1 \mathrm{~A} 1 \mathrm{i}+\beta 2 \mathrm{G} 2 \mathrm{i}+\beta 3 \mathrm{Ndep} 3 \mathrm{i}-\beta 4 \mathrm{ES} 4 \mathrm{i}-$ $\beta 5$ LeEd5i - $\beta 6$ AMIPS6i - $\beta$ 7ASMH7i - $\beta 8$ DC8i $\beta 9 P r e m 9 i-\beta 10 L I 10 i-\beta 11 I A 11 i-\beta 12 F L 12 i-$ $\beta 13$ T13i - $\beta 14$ RA14i - $\beta 15 R 15 i+\beta 16$ PI16i + $\varepsilon i$

Where $\mathrm{Y}_{i}$ is dependent variable i.e the demand for micro-insurance represented by five categories Credit Life Micro-insurance, Health Micro-insurance, Property Micro-insurance, Livestock Microinsurance and Crop Micro-insurance products. $\beta$ is coefficients for the respective variables and $\mathrm{A} 1 \mathrm{i}=$ age, $\mathrm{G} 2 \mathrm{i}=$ Gender, Ndep3i= Number of dependents, ES4i = Employment Status, LeEd5i= Level of education, AMIPS6i = Availability of micro-insurance product supply, ASMH7i= Adverse selection and Moral Hazard, DC8i= Delivery Channel, Prem9i $=$ Premium,LI10i $=$ Level of Income, IA11i $=$ Insurable Asset, FL12i = Financial Literacy, T13i $=$ Trust, $\mathrm{RA} 14 \mathrm{i}=$ Risk Aversion, R15i = Religion and PI16i Peer Influence and $\varepsilon_{\mathrm{i}}$ is the error term which represent variables which are not captured by the current model.

Variable description and its measurements was presented as follows in table 1.

\section{RESULTS AND DISCUSSION}

Test Result for Multinomial Logistic Regression Model

MNL model requires the fulfillment of the assumption of the Independence of Irrelevant Alternatives (IIA), otherwise the model will be inappropriate. The study had used HausmanMcFadden test of independence of irrelevant alternatives. The Hausman-McFadden tests results indicate that there is strong evidence that we fail to reject the null hypothesis indicating that our assumption for independence of irrelevant

Table 1. Variable definition and Measurements

\begin{tabular}{|c|c|}
\hline Variables & Measurements \\
\hline \multicolumn{2}{|l|}{ Dependent variable } \\
\hline Micro-insurance Demand & $\begin{array}{l}1=\text { Credit Life Micro-insurance }, 2=\text { Health Micro-insurance, } 3= \\
\text { Property Micro-insurance and } 4=\text { Livestock Micro-insurance } \\
5=\text { Crop Micro-insurance }\end{array}$ \\
\hline \multicolumn{2}{|l|}{ Independent variable } \\
\hline Age & Age of respondent \\
\hline Gender & Females $=1$, otherwise $=0$ \\
\hline Household size/Dependency ratio & Number of people in a single household \\
\hline Employment status & Employed $=1$, otherwise $=0$ \\
\hline Education & Schooling years of head of household \\
\hline Adequate micro-insurance product supply & Yes $=1$, otherwise $=0$ \\
\hline Adverse selection and moral Hazard & Yes $=1$, otherwise $=0$ \\
\hline Lack of delivery channel & There is enough delivery channel $=1$, otherwise $=0$ \\
\hline Premium & Premium high $=1$, otherwise $=0$ \\
\hline Level of income & Monthly income of head of household in ETB \\
\hline Insurable Asset & Asset owned by household \\
\hline Financial Literacy & Financially literate $=1$, otherwise $=0$ \\
\hline Trust & Trust insurance companies $=1$, otherwise $=0$ \\
\hline Risk Aversion & Feel exposed to risk $=1$, otherwise $=0$ \\
\hline Religion & Christian/Muslim $=1$, otherwise $=0$ \\
\hline Peer influence & Peer influence $=1$, Otherwise $=0$ \\
\hline
\end{tabular}

Source;- Empirical Review 
alternatives (IIA) is satisfied. In addition, test for multicolliniarity was conducted by using VIF and the result shows that multicolliniarity is not a severe problem in this model. Goodness of fit test was conducted to test the null hypothesis which assumes that all of the regression coefficients across both models are simultaneously equal to zero and the result suggests that the model has a strong explanatory power.

\section{Result of multinomial regression model}

Table 2 gives the multinomial logistic -estimation results for the factors influencing household's choice of specific micro-insurance product. The base outcome for the model was credit life micro-insurance. This indicates that the following discussion of the results emphasize on the effect of the independent constructs on a specific micro-insurance purchase relative to credit life micro-insurance. Coefficient estimations from the multinomial logistic model can tell about the direction effect or likelihood effect than the magnitude effect. We see how can compute the magnitude of effect by using STATA 13 command margins after multinomial logistic regression and it give marginal effect or elasticity to explain the effects of the independent variables on microinsurance demand in the study area.

Table 2 lists estimates of the marginal effects of the independent variables on the probabilities associated with outcomes. The pseudo-R square for the model was 0.3179 this implies that 31.79 percent of the variation in the dependent variable is explained by the explanatory variables. Thus, the independent variables offer a good explanatory power for determining household's decision to adopt one of the five alternatives of microinsurance products. The likelihood ratio statistics as indicated by ch2 statistics (LR chi-square $(64)=397.75$ are highly significant $(P<0.0000)$, suggesting the model has a strong explanatory power. In all cases, the estimated coefficients should be compared with the base category of credit life insurance.
As indicated in the above table 2 household size, employment status, level of education, adequacy of micro-insurance supply, delivery channel, premium, monthly income, Insurable asset, financial literacy, trust and risk aversion has significant impact on the demand for microinsurance products, whereas age, Gender, adverse selection and moral hazard, religion and peer influence has insignificant impact on household's demand for micro-insurance products.

\section{In-depth interview results}

In depth interviews were conducted with 12 top officials of insurance and microfinance institutions. The interview result shows that product design risk, high transaction cost, low staff productivity and efficiency, inadequate distribution channels, adverse selection and moral hazard are the main factors that affect adequate micro-insurance supply and quality of micro-insurance service. In relation to types of micro-insurance products the interview result confirmed that most available micro-insurance products provided by commercial insurers and (other formal and informal) financial sectors in Jimma zone are credit life microinsurance and agricultural micro-insurance. Like in many other developing countries agricultural micro-insurance is offered in the form of weather index insurance, multi-peril crop micro-insurance, named peril crop micro-insurance, and livestock micro-insurance. While a few pilot projects have been implemented, a majority of them are yet on the way particularly in the area of agricultural insurance and health insurance. The usual providers of micro-insurance in Jimma Zone are commercial insurers, MFIs, coffee unions, and donors. Coffee unions and MFIs, in terms of client bases, are leading the delivery of financial services to low-income households. However, donors played the most important role in the development of micro-insurance by providing funds, capacity building and technical assistance.

\section{Discussions}

This section discusses some of the main 
Table 2. Marginal effect of multinomial logistic regression result

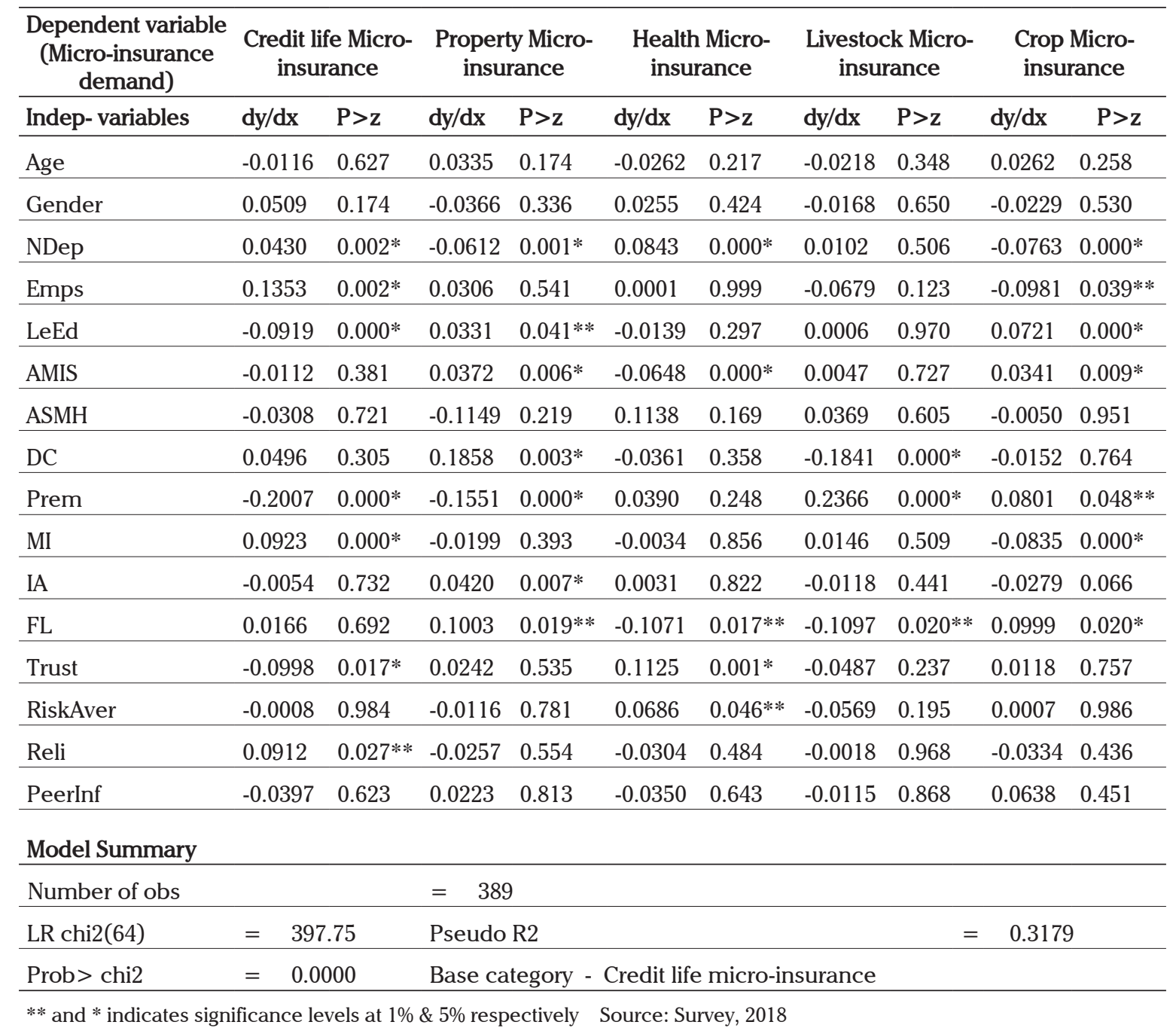

$* *$ and $*$ indicates significance levels at $1 \%$ \& $5 \%$ respectively Source: Survey, 2018

implications of the regression, in-depth interview results and significant factors that affect microinsurance demand in Jimma zone. The result of this study clearly shows that delivery channel, premium, adequacy of micro-insurance products and financial literacy have influential impact on household's demand for micro-insurance products thus micro-insurance providers need to innovative micro-insurance products that reduce transaction costs through the development of cost-effective delivery channels, and charging affordable premium is vital to increase household's demand for micro-insurance products. In addition, intervention mechanisms required by microinsurance providers by involving a series of capacity building activities focused at increasing the poor's knowledge of micro-insurance concepts, skills, and attitudes and to translate this knowledge into behaviors that results in good outcomes for both micro-insurance providers and users.

\section{Household size}

There was a positive marginal effect of 0.0805 between household's size and the subscription to health micro-insurance and a negative marginal effect of 0.0612 and 0.0763 between household's size and the subscription to property and crop micro-insurance scheme respectively relative to credit-life insurance at a statistical significance level of 1percent. The positive relationship between household size and subscription to health microinsurance implies that as the number of family 
members increased by 1 individual the probability to subscribe health micro-insurance increased by 0.0805 . The result was consistent with a study by Dror et al. (2007) which also found household size as the key significant determinant of household's readiness to purchase health micro-insurance as the size of the household increases, hence the families desire to purchase micro-insurance is not meant to cover only the key source of income, but include the entire family. On the other hand, the negative relationship between household size and subscription to property and crop micro-insurance scheme implies that as the number of family members increased by 1 individual the probability to subscribe property and crop micro-insurance decreased by 0.0612 and 0.0763 respectively. The finding was consistent with previous study by Ito and Kono (2010) which found negative link between the demand for micro health microinsurance products and household size.

\section{Employment status}

There was a negative marginal effect of -0.0981between the employment status of household heads and their subscription to crop micro-insurance products relative to creditlife micro-insurance at a statistical significance level of 5percent. This therefore indicates that the unemployed household heads have less probability of subscribing to micro-insurance products relative to their employed counterparts. This finding was consistent with Bendig et al. (2010) which found negative relationship between household's demand for micro health insurance products and employment status.

\section{Level of education}

There was a positive marginal effect of 0.0331 and 0.0721 between the education of household heads and their subscription to property and crop micro-insurance products relative to creditlife micro-insurance at a statistical significance level of 5percent and 1percent respectively. This implies that better education level has assumed with better tendency for purchase of micro- insurance products, as it may initiate the ability of households to comprehend the advantages of risk administration and savings, even though, it increases individual's risk aversion attitude the finding was consistent with (Beck \& Webb, 2002). Furthermore, educated family units will probably take up protection (Chankova et al., 2008; Giné et al., 2008), the findings of (Chankova et al., 2008; Ito \&Kono, 2010). Bendig et al. (2010), Giesbert et al. (2011) and Bendig and Arun (2011) also confirmed that educated family heads have greater probability to comprehend such a product more easily, and be more likely to participate in that kind of micro-insurance product relative to lesser formally educated.

\section{Adequacy of micro-insurance product supply}

There was a positive marginal effect of 0.03410 .0372 between adequacy of micro-insurance product supply and household's subscription to property and crop micro-insurance scheme respectively and there was a negative marginal effect of 0.0648 between adequacy of micro-insurance product supply and household's subscription to health micro-insurance relative to credit-life micro-insurance at a statistical significance level of 1percent. The positive relationship between adequacy of micro-insurance product supply and household's subscription to property and crop micro-insurance scheme implies that high quality adequate micro-insurance products increase in the household's subscription of micro-insurance products. On the other hand, the negative relationship between adequacy of micro-insurance product supply and household's subscription to health micro-insurance is due to the fact that the risk reduction potential of the existing microinsurance products is insufficient. As a result, the demand for micro-insurance becomes low, when there is not adequate product provision.

\section{Lack of delivery channel}

There was a negative marginal effect of 0.1841 and a positive marginal effect of 0.1858 between delivery channel and household's subscription to 
livestock and property micro-insurance scheme respectively relative to credit-life micro-insurance at a statistical significance level of 1percent. The positive relationship between delivery channel and household's subscription to property microinsurance implies that if micro-insurance products are accessible to the poor with low cost distribution channels increases the probability of household's subscription to micro-insurance products. On the other hand, the negative relationship between delivery channel and household's subscription to livestock micro-insurance due to the fact that in Ethiopia in general Jimma zone in particular most insurers are often constrained by lack of low cost distribution channels that can reach low-income earners' target market so lack of delivery channel affects household's subscription to livestock micro-insurance, the finding is consistent with the interview result lack of low cost distribution channels that can reach low-income earners' target market is the main factor that affect microinsurance supply and demand. The finding is also consistent with (McCord et al., 2005; Roth et al., 2007; Amit, 2010; Leazerman et al., 2010;Akotey et al., 2011; Smith and Chamberlain, 2010; Araya,2011 ;Shifa, 2012 ;Tadesse and Victor, 2012;) which found lack of delivery channel as a major obstacle for micro-insurance demand.

\section{Premium}

There was a negative marginal effect 0.1551 between premium and household's subscription to property micro-insurance relative to creditlife micro-insurance at a statistical significance level of 1percent and there is a positive marginal effect of 0.2366 and 0.0801 between premium and household's subscription to livestock and crop micro-insurance relative to credit-life microinsurance at a statistical significance level of 1percent and 5percent respectively. The negative relationship between premium and household's subscription property micro-insurance is due to the fact that to access the poor insurers incurs high transaction cost and the increased costs must be included in the premiums, increasing the cost of insurance which affect the households demand negatively and the finding was consistent with the interview result. This finding is consistent with result of the study of Cole et al. (2013) that showed that significant price sensitivity for rainfall insurance demand in India. On the other hand, positive relationship between premium and household's subscription livestock and crop micro-insurance implies that low-income people buy micro-insurance if the products meet their needs and are fairly priced hence setting affordable price for insurance increases the probability of household's subscription to livestock and crop micro-insurance products. The finding was consistent with Christiana, (2016) which found positive relationship between price and household's subscription to property microinsurance demand.

\section{Level of income}

There was a negative marginal effect 0.0835 between level of income and household's subscription to crop micro-insurance scheme relative to credit-life micro-insurance at a statistical significance level of 1percent, this indicates that households with low monthly income levels have less probability of subscribing to crop micro insurance product this is due to the fact that lowincome people buy micro-insurance if the products meet their needs and are fairly priced (affordable) the finding was also consistent with the result of descriptive statistics which shows that majority of non- subscribers of micro-insurance earns low monthly income.

\section{Insurable Asset}

There was a positive marginal effect of 0.0420 between insurable assets and household's subscription to property micro-insurance scheme relative to credit-life micro-insurance at a statistical significance level of 1percent. This implies that the availability of insurable property is a triggering factor for demand of micro-insurance. Because, individual's need to safeguard their assets from unexpected loss. The finding was consistent with 
previous researchers (Kakar and Shukara, 2010; Huber, 2012; Bendig and Arun, 2011; Kaume and Komenon, 2012).

\section{Financial Literacy}

There was a positive marginal effect of 0.1003 and 0.0999 between financial literacy and household's subscription to property and crop micro-insurance respectively relative to credit-life micro-insuranceat a statistical significance level of 5percent and there was a positive marginal effect of 0.1071 and0.1097 between financial literacy and household's subscription to health and livestock microinsurance scheme respectively relative to creditlife micro-insurance at a statistical significance level of 5percent. The positive relationship between premium and household's subscription property and crop micro-insurance implies that households with higher level of financial literacy have higher level of purchasing micro-insurance products. The finding was consistent with Cai and Song (2011) and Norton et al. (2011) who also reported positive relationship between financial literacy and households purchase of microinsurance products. On the other hand, negative relationship between premium and household's subscription livestock and crop micro-insurance implies that households with lower financial literacy levels have less probability of subscribing to property micro-insurance products. The finding was consistent with Christiana,(2016) which found negative relationship between financial literacy and households subscription to property microinsurance.

\section{Trust}

There was a positive marginal effect of 0.1125 between trust of households and subscription to health micro-insurance scheme relative to creditlife micro-insurance at a statistical significance level of 1percent. This implies that higher level of trust of households in the insurance product and the insurer and/or potential intermediary have greater probability of purchasing micro-insurance schemes. The finding was consistent with previous researchers Akotey et al. (2011) ,Morsink and Geurts (2011) and Cole et al. (2013).

\section{Risk Aversion}

There was a positive marginal effect of 0.0686 between risk aversion of households and subscription to health micro-insurance scheme relative to credit-life micro-insurance at a statistical significance level of 5percent. This implies that individuals that are relatively more risk-averse have greater probability of purchasing micro-insurance schemes. The finding was consistent with previous researchers Cole et al. (2013), Kouame and Komenan (2012) and Giesbert et al. (2011).

\section{MANAGERIAL IMPLICATIONS}

The study has an implication for policy makers and academicians to understand the role of delivery channel on micro-insurance demand and devising effective and efficient delivery channels that can add value to the bottom line by considering customer, product, and context of organization, cost and environmental factors. In addition, to reach millions of low-income households in rural and urban areas, designing different innovative distribution channels which lower transaction costs and using partner agent model proved successful in reaching a large portion of the population and such arrangement is helpful to Ethiopian micro-insurance industry.

An important practical implication of our study is that improvement in individual's financial literacy increases the probability that an individual will own micro-insurance insurance product and any financial literacy enhancement program have favorable implications for successful microinsurance service delivery.

Moreover, micro-insurance schemes are price elastic and hence any possible or adjustable lowering of premium or price to affordable level could increase quantity demand by more than proportionately and hence result to greater increase in total revenues to the service providers.. 


\section{CONCLUSION}

Micro-insurance in most developing countries has now become a well-accepted component of financial inclusion strategies and is increasingly being seen as a tool not only for social protection but also for equitable mitigation of risks thereby spurring poverty alleviation and economic development and many factors influence a household's decision to buy micro-insurance. To this end, this study sought to investigate determinants of household's micro-insurance demand in Jimma zone. In order to achieve this objective, one research questions and sixteen hypotheses have been developed and tested. To address the research questions, test hypotheses and achieve the broad research objective, the study used mixed research approach. More specifically, the analyses were performed using data collected from households through questioner and in-depth interview were conducted with operational and marketing department (practitioners). Multinomial logistic regression model was used to estimate the regression equation.

The interview result shows that product design risk, high transaction cost, low staff productivity and efficiency, inadequate distribution channels, adverse selection and moral hazard are the main factors that affect adequate micro-insurance supply and quality of micro-insurance service.

In relation to types of micro-insurance products the interview result confirmed that most available micro-insurance products provided by commercial insurers and (other formal and informal) financial sectors in Jimma zone are credit life microinsurance and agricultural micro-insurance. Like in many other developing countries agricultural micro-insurance is offered in the form of weather index insurance, multi-peril crop micro-insurance, named peril crop micro-insurance, and livestock micro-insurance. While a few pilot projects have been implemented, a majority of them are yet on the way particularly in the area of agricultural insurance and health insurance. The usual providers of micro-insurance in Jimma Zone are commercial insurers, MFIs, coffee unions, and donors. Coffee unions and MFIs, in terms of client bases, are leading the delivery of financial services to low-income households. However, donors played the most important role in the development of micro-insurance by providing funds, capacity building and technical assistance.

Regarding the determinants of micro-insurance demand household size, employment status, level of education, adequacy of micro-insurance supply, delivery channel, premium, monthly income, Insurable asset, financial literacy, trust and risk aversion has significant impact on the demand for micro-insurance products, whereas age, Gender, adverse selection and moral hazard, religion and peer influence has insignificant impact on household's demand for micro-insurance products whereas, age, Gender, adverse selection and moral hazard, religion and friend and family influence has insignificant impact on household's demand for micro-insurance products this suggests that there influences on household's demand for micro-insurance products negligible. 
REFEREN CES

Akotey O J Kofi, A Osei, Albert G 2011,'The demand for micro-insurance in Ghana',

Amit, K 2010, 'Micro-insurance-risk protection for 4 billion people', Swiss Reinsurance Company Ltd. Economic research and consulting

Araya 2011, 'Weather Insurance for Farmers: Experience from Ethiopia'- Paper presented at the IFAD Conference on New Directions for Smallholder Agriculture 24-25

Beck, T., \& Webb, I. (2003). Economic, Demographic, and Institutional Determinants of Life Insurance Consumption. The World Bank Economic Review, 17(1), 51-88.

Bendig, M, \& Arun, T 2011, 'Enrolment in Micro Life and Health Inusrance', Evidences from Sri Lanka. Bonn: IZA DP No. 5427.

Bendig, M., Giesbert, L. \& Steiner, S. (2010): Savings, Credit and Insurance: Household Demand for Formal Financial Services in Rural Ghana, GIGA Working Paper Series, No. 94, January 2010, Hamburg: German Institute of Global and Area Studies.

Cai, J., and Song, C. (2011), Insurance take up in rural China: Learning from hypothetical experience, Mimeo.

Chankova, S., Sulzbach, S. \& Diop, F. (2008): Impact of mutual health organizations: evidence from West Africa, Health Policy and Planning, 23(4): 264-276.

Christiana B., (2016) Determinants of the demand for micro-insurance in Ghana unpublished master's thesis.

Clarke, D \& Kalani, G 2011, 'Microinsurance Decisions': Evidence from Ethiopia. Mimeo, University of Oxford, 1-43.

Cole, S., Giné, X., Tobacman, J., Topalova, P. B., Townsend, R. M., and Vickery, J. I. (2013) 'Barriers to household risk management: evidence from India', American Economic Journal: Applied Economics 5(1): 104-135.

Dercon, S., Gunning, J.W. and Zeitlin, A. (2011). The demand for insurance under limited credibility: Evidence from Kenya. International Development.

Dror, D.M., Radermacher, R. \& Koren, R. (2007): Willingness to Pay for Health Insurance Among Rural and Poor Persons: Field Evidence from Seven Micro Health Insurance Units in India, Health Policy, Vol. 82, No. 1.

Eling, M., Pradhan S., \& Schmit J., (2013), The Determinants of Micro-insurance Demand. Working Papers on Finance No. 2013/8.

Feldstein, M. (1973). The welfare loss of excess health insurance. Journal of Political Economics, 81: 251-280

Giesbert, L., Steiner, S., \& Bendig, M. (2011). Participation in Micro Life Insurance and the Use of Other Financial Services in Ghana. The Journal of Risk and Insurance, 78, 7-35.

Giné X., Townsend, R., and Vickery, J. (2008) 'Patterns of rainfall insurance participation in rural India', World Bank Economic Review 22(3): 539-566.

Huber, F. (2012). Determinants of Microinsurance Demand: Evidence from a Micro Life Scheme in Indonesia. Finance Master's thesis: Department of Finance Aalto University School of Economics.

Ito, Seiro and Hisaki Kono (2010): Why is the Take-up of Microinsurance so Low? Evidence from a Health Insurance Scheme in India, The Developing Economies 48 (1), pp. 74-101.

Jowett, M. (2003) 'Do informal risk sharing networks crowd out public voluntary health insurance? Evidence from Vietnam', Applied Economics 35(10): 1153-1161.

Kakar, P and Shukla, R 2010, 'The Determinants of Demand for Life Insurance in an Emerging EconomyIndia Margin' The Journal of Applied Economic Research

Kouame, E B H Komenan Aka, Narcisse 2012, 'Risk preferences and demand for insurance under price uncertainty' an experimental approach for cocoa farmers in côte d'ivoire

Leazerman S Lisa J C Gillings, Kenan, F Jeanna, H 2010, ‘Innovations and barriers in health micro-insurance' ILO's Microinsurance Innovation Facility..

McCord M J Gaby, R Elizabeth, M 2005, 'Micro-insurance Demand \& Market Prospects Lao People's Democratic Republic'mimeo, 1-34.

Micro-insurance Network (2016) The Landscape of Micro-insurance in Africa, published by Micro-insurance network, Munic re foundation and micro-insurance center.

Morduch, J. (2006), «Microinsurance: the next revolution?» In Understanding Poverty (A. Banerjee, R. Benabou, and D. Mookherjee, eds.), Oxford University Press, New York, NY.

Morsink and Geurts 2011, 'The trusted neighbor effect: Local experience and demand for micro-insurance'

Mossin, J 1968, 'Aspects of Rational Insurance Purchasing' Journal of Political Economy. Vol. 76, 533-568.

Ndurukia et.al 2017 the determinants of demand for micro-insurance services in Kenya American Journal of Finance ISSN 2520-0445 (Online) Vol.2, Issue 6 No.3, pp 79 - 107, 2017

Norton M Daniel, O Malgosia, M Eric, H 2010, 'Evidence of Demand for Index Insurance' Experimental Games and Commercial Transactions in Ethiopia of Finance, 63(6), 2557-2600. 
Pratt, J.W. (1964). Risk Aversion in the Small and in the Large. Econometrical: Journal of the Econometric Society, 32(1): 122136

Roth, J Michael, J McCord, and Dominic, Liber 2007, 'The Landscape of Microinsurance in the World's 100 Poorest Countries.' Appleton, WI. The MicroInsurance Centre, LLC..Journal of Risk Finance, Vol. 12 Iss: 3 pp. 182 - 194

Saqware, A. N. (2012). Micro-insurance in Tanzania: Demand Perspectives. A Thesis Submitted in the Partial Fulfillment of the Requirements for the Degree of Doctor of Philosophy at the University of Central Lancashire. pp. 1-224.

Schlesinger, H. and Doherty, N.A. (1985). Incomplete Markets for Insurance: An Overview. The Journal of Risk and Insurance, 52(3): 402-423.

Shifa, M 2012, 'The Landscape of Micro-Insurance In Ethiopia: Exploring Opportunities And Challenges', NBE National bank of Ethiopia 2012, Birritu bulletin; volume number, 112

Smith \& Chamberlain 2010, 'Opportunities \& challenges of micro-insurance in Ethiopia' A report Commissioned by the International Labor Organization and United Nations Capital Development Fund. January. Oxfam America: Boston, MA.

Tadesse and Brans 2012, 'Risk, coping mechanisms, and factors in the demand for micro-insurance in Ethiopia' Journal of Economics and International Finance Vol. 4(4), pp. 79-91, 22

Thornton, R. L., Hatt, L. E., Field, E. M., Islam, M., Sol’ Diaz, F., and Gonzalez, M. A. (2010) 'Social security health insurance for the informal sector in Nicaragua: A randomized evaluation', Health Economics 19(S1): 181-206. 